\author{
ĐurĐica ČIllí Š Keljo ${ }^{1}$ \\ Wydział Filozoficzny \\ Uniwersytet w Zagrzebiu
}

\title{
MOTYW SAMOBÓJSTWA WE WSPÓŁCZESNEJ POEZJI POLSKIEJ
}

W ciągu ostatnich kilku miesięcy uwagę europejskiej opinii publicznej przykuła seria samobójstw zubożałych i pozbawionych swoich praw Bułgarów oraz Włochów. Są one odczytywane przede wszystkim jako symptomy kryzysu. Samobójcy będący ofiarami poważnego krachu gospodarczego i finansowego, to jednostki dotknięte skrajnym ubóstwem, społecznie i klasowo zdegradowane do tego stopnia, że ich biologiczne życie stanowi jedyną własność, którą mają prawo dysponować. Akt samobójstwa jest w tym kontekście wyrzeczeniem się życia sprowadzonego do biologicznej egzystencji. Podobnie jak w przypadku terrorystycznych zamachów samobójczych, może ono stanowić również gest polityczny; z tym że w przypadku bułgarskich i włoskich desperatów w grę wchodzi świadome samowykluczenie ze społeczeństwa odrzucającego tych, którzy odstają, przeszkadzają, stanowią nadmiar i produkują koszty, są niepotrzebni i/lub irrelewantni. W takim ujęciu samobójstwo jest zwykle potwierdzeniem czy też forpocztą działania systemu ukierunkowanego na jednostkę; działania, jakim jest wyniszczanie.

Co czterdzieści sekund gdzieś na świecie jedna osoba popełnia samobójstwo. Samobójstwa artystów, a szczególnie pisarzy, często uznawane są za bardziej intrygujące, tym samym może się wydawać, że jest ich więcej. Liczba pisarzy-samobójców zatrważa, nie ulega jednak wątpliwości, że nie przewyższa ona liczby samobójstw popełnianych przez przedstawicieli innych profesji. Według statystyk, największa liczba samobójstw zdarza się wśród lekarzy. Pisarze jednak, za sprawą swojego specyficznego stosunku do języka, mają szczególny stosunek do śmierci, a więc także do samobójstwa².

Zgodnie z psychospołeczną teorią suicydologiczną, której podstawy pod koniec XIX wieku sformułował Emile Durkheim³ ${ }^{3}$ samobójstwa można podzielić na trzy ka-

${ }^{1}$ Đurđica Čilić Škeljo - studiowała kroatystykę i polonistykę na Uniwersytecie w Zagrzebiu, gdzie w 1999 roku obroniła pracę dyplomową, w 2005 roku pracę magisterską, a w roku 2010 pracę doktorską. Obecnie pracuje na Katedrze Języka i Literatury Polskiej na Uniwersytecie w Zagrzebiu. Brała udział w 15 konferencjach naukowych w Chorwacji, Słowenii i w Polsce. Zajmuje się głównie polską liryką XX wieku i najnowszą. Tłumaczy literaturę polską, w tym głównie poezję, na język chorwacki.

${ }^{2}$ R. Ruby, Paradoxes on Suicide and Literature [online], dostęp 5 maja 2014, dostępny: <http://thenewinquiry.com/ /essays/paradoxes-on-suicide-and-literature>.

${ }^{3}$ Zob. E. Durkheim, Samoubistvo, Belgrad 1977. 
tegorie: samobójstwa egoistyczne, altruistyczne i anomiczne. Samobójstwo egoistyczne dotyczy ludzi, którzy stacili zainteresowanie społecznym aspektem życia lub tych, którzy nie zintegrowali się całkowicie i prawidłowo ze społeczeństwem. Są to najczęściej ludzie upośledzeni fizycznie i niezrównoważeni społecznie, nierzadko charakteryzujący się rozmaitymi zaburzeniami psychicznymi. Samobójstwo altruistyczne jest dobrze znane w grupach religijnych, społecznych lub politycznych. Dotyczy jednostek, które składają siebie w ofierze za resztę grupy lub w imię celów danej wspólnoty. Georges Minois w swojej Historii samobójstwa zadaje prowokacyjne pytanie: „Czyż śmierć Chrystusa nie jest prawdziwym samobójstwem?” Zadane w tak brutalnej formie pytanie szokuje. Jednakże, czym innym jak nie jasnym potwierdzeniem dobrowolnego wyboru śmierci są słowa, które św. Jan przypisuje Jezusowi: „Nikt mi go (tj. życia) nie zabiera, lecz ja od siebie je oddaję" i „Życie moje oddaję za owce”. Czyż nie potwierdzają one wyboru nazywanego obecnie samobójstwem ${ }^{34}$ Co więcej, Minois stawia tezę, że to właśnie samobójstwo jest kamieniem węgielnym chrześcijaństwa — w relacjach uczniów podkreślana jest ta dobrowolna ofiara i przykład Chrystusa śledzą liczni męczennicy za wiarę. Samobójstwo anomiczne pojawia się natomiast wtedy, gdy dochodzi do znaczących zmian społecznych, ekonomicznych lub dezintegracji kultury. Przyczyną myśli samobójczych jest w tym przypadku zmiana pozycji społecznej jednostki. Durkheim uważa, że właściwy dla danego społeczeństwa odsetek samobójstw jest wynikiem różnego stopnia socjalnego powiązania jednostki ze społeczeństwem. Jednostka może być niedopasowana do społeczeństwa lub też samo społeczeństwo może jej narzucić zachowania samobójcze, co więcej, w określonych sytuacjach może ich wręcz wymagać (harakiri u Japończyków, samobójstwa starców wśród Eskimosów, sati, czyli rytualne palenie wdów w Indiach).

Perspektywa socjologiczna ma jednak swoje ograniczenia: otóż Durkheim nie dostrzega różnicy pomiędzy samobójcami, którzy w ten sposób „uciekają” na przykład od prawomocnej kary za popełnione przestępstwo (osoba, która dobrowolnie wybiera śmierć, stawia się całkowicie poza zasięgiem ludzkiej mocy), a samobójcami, którzy poświecając życie, ponoszą ofiarę, innymi słowy ratują życie innej osoby5. Jeśli jednak za kluczowe kryterium przy definiowaniu samobójstwa uznamy z jednej strony świadomość podmiotu, dzięki której zdaje on sobie sprawę z tego, co robi i sam decyduje się na podjęcie tego działania, a z drugiej natomiast uwypuklimy wagę samego czynu, zaś nie motyw, wówczas samobójstwo zawsze będzie zagadnieniem o wymiarze socjologicznym i politycznym.

Istnieją wiarygodne, w większości pisane, dowody na to, że ludzie jeszcze w okresie antycznym sami wybierali moment własnej śmierci. Społeczeństwo nigdy nie było wobec tego aktu obojętne. Rzadko ujmowane było ono w kategoriach czynu bohaterskiego, dużo częściej było przedmiotem pogardy lub krytyki. Jak stwierdza Minois,

${ }^{4}$ G. Minois, Istorija samoubistva. Dobrovoljna smrt u zapadnom drusttvu, przekł. O. Petronić, Novi Sad 2008, s. 36-38.

${ }^{5}$ Zob. T. Ślipko, Etyczny problem samobójstwa, Kraków 2008, s. 141. 
sam termin „samobójstwo” pojawia się w roku 1700 i zastępuje stosowane wcześniej sformułowanie „zabójstwo samego siebie”, co w naszej epoce oznacza również zmianę stosunku względem tej kwestii, której początki datują się na okres renesansu. Wcześniej bowiem w społeczeństwach zachodnich, silnie naznaczonych wartościami chrześcijańskimi, samobójstwo traktowane było jako obraza Boga, który dał człowiekowi życie i zobowiązał go do służenia sobie i społeczeństwu. W dobie renesansu ocenianie samobójstwa przez pryzmat chrześcijaństwa zostaje podane w wątpliwość i stopniowo odchodzi się od tego stanowiska ${ }^{6}$. Sama kwestia samobójstwa do dziś stanowi istotny problem w wymiarze filozoficznym, psychologicznym, medycznym, moralnym, kulturowym, religijnym, itd.

Zarówno w perspektywie synchronicznej, jak i diachronicznej, samobójstwo nie jest czynem jednoznacznym i posiada różne formy. Żołnierze, którzy z własnej woli ruszają do walki z silniejszym wrogiem, dobrowolni męczennicy, którzy w imię określonej idei odmawiają przyjęcia pomocy, chorzy, którzy nie chcą być leczeni, terroryści-samobójcy, którzy giną zabijając innych, ludzie, którzy wybierają śmierć, ponieważ chcą uniknąć ciężkiego życia, poniżenia lub kary oraz samobójstwa, w których ofiaruje się własne życie, by uratować cudze - to przykłady pośredniego lub bezpośredniego samobójstwa. Choć ich powody znacznie się od siebie różnią, zamiar i rezultat są takie same — śmierć.

W literaturze często spotyka się wspomniane motywy, a samo samobójstwo zwykle pokazywane jest w pozytywnym świetle, co potwierdzają chociażby klasyczne tragedie, w których bohaterowie w imię ideałów wybierają heroiczną śmierć lub tragiczne postacie literackich samobójców pojawiające się w literaturze zachodnioeuropejskiej w okresie oświecenia, ginących, aby zachować honor, a także samobójstwa altruistyczne, samobójstwa męczenników lub samobójstwa z miłości. Imponująca jest też liczba samobójstw w literaturze romantycznej ${ }^{7}$. Niemniej jednak nasuwa się pytanie, czy samobójstwo jako temat literacki zawsze i wyłącznie było częścią estetycznego wyobrażenia śmierci rodem z poprzednich epok, zwłaszcza z okresu romantyzmu? Stosunkowo powszechne jest stwierdzenie, iż estetyczne wyobrażenie śmierci stanowi „część estetycznego sposobu życia" ${ }^{\prime}$. Psychoanaliza takie kreatywne posługiwanie się śmiercią uznaje za ważną formę sublimacji — osoba sublimuje swoje popędy, w wyniku czego powstają dzieła sztuki ${ }^{9}$. Na uwagę zasługuje jednak fakt, iż samobójstwo tzw. zwykłych ludzi nigdy nie jest przedmiotem zabiegów estetycznych, zawsze jest ono przyziemne i wulgarne, jednym słowem — nudne. Dlatego też postrzegane jest wyłącznie w kategoriach danych statystycznych, ewentualnie jako rezultat i potwierdzenie lekarskiej

\footnotetext{
${ }^{6}$ Zob. G. Minois, Istorija samoubistva. Dobrovoljna smrt u zapadom drusttvu, przekł. O. Petronić, Novi Sad 2008, s. 88 .

${ }^{7}$ Zob. G. Minois, dz. cyt., s. 261.

${ }^{8}$ Zob. K. Kuczyńska-Koschany, Dwa paradygmaty samobójstwa, czy dwa akty wolnej śmierci? [online], dostęp 4 marca 2014, dostępny: <https://repozytorium.amu.edu.pl/jspui/bitstream/10593/6405/1/ 01Koschany-p.pdf>.

${ }^{9}$ Zob. R. Salecl, Tiranija izbora, przekł. T. Valentić, Zagreb 2012, s. 150-151.
} 
diagnozy. Tym samym pozostaje wyłącznie w domenie medycyny i socjologii. Natomiast samobójstwa filozofów i pisarzy zawsze postrzegane są jako intelektualnie inspirujące, zaś samobójstwa artystów jako frapujący czyn, silnie oddziałujący na wyobraźnię.

Atrakcyjny i wyraźnie uwidaczniający się motyw samobójstwa we współczesnej polskiej poezji obecny jest na dwa sposoby: jako tematyzacja lub zapowiedź samobójstwa własnego oraz jako refleksja czy też opracowanie liryczne cudzej śmierci samobójczej. W artykule na przykładach wierszy wybranych z korpusu współczesnej polskiej poezji, spróbuję przeanalizować podobieństwa i różnice poetyckiej prezentacji tych dwóch typów samobójstwa - własnego i cudzego. Omawiany motyw samobójstwa, zgodnie z ujęciem filozoficznym, traktuję w swoich rozważaniach jako czyn autentyczny. Poprzez pozycjonowanie samobójczego lirycznego „ja”, „ty” lub „on”, spróbuję opisać relacje semantyczne zachodzące pomiędzy poezją, poetą i śmiercią.

Punkt wyjścia moich rozważań stanowi teza głosząca, iż poetów możemy z grubsza podzielić na tych, którzy sami są społecznie zmarginalizowani czy też nieco upraszczając — są ,"bez szansy na sukces” oraz na tych, którzy zyskali uznanie społeczne i pozycję w świecie literackim. Tak odmienne pozycje warunkują różne podejście do motywu samobójstwa. Świetny przykład stanowią Zbigniew Herbert, Wisława Szymborska, Urszula Kozioł z jednej oraz Rafał Wojaczek i Edward Stachura z drugiej strony. Troje poetów wspomnianych w pierwszej kolejności w swoich znanych wierszach porusza temat cudzego samobójstwa (Szymborska: Pokój samobójcy, Herbert Samobójca, Pan Cogito o postawie wyprostowanej, Kozioł Temu kto postanowit odejś́ sam), a Wojaczek (w wierszach Koniec świata, Początek wiersza, Chodze i pytam) i Stachura (wiersze List do pozostalych, Biała lokomotywa) własnego. Dzisiaj są to, za wyjątkiem Urszuli Kozioł, która nadal żyje, poeci, którzy zdołali sobie zapewnić życie po śmierci, przynajmniej na jakiś czas, niezależnie od tego, czy swoje życie społeczne, biologiczne zakończyli dobrowolnie czy też zmarli śmiercią naturalną. Na dychotomiczną wizję samobójstwa w literaturze składają się obrazy, w których targnięcie się na własne życie jest czynem bohaterskim lub czynem tchórzowskim. Przywołana pozytywna bądź negatywna konotacja nie jest koniecznie związana z tym, czy tematem jest własna czy też cudza dobrowolna śmierć. Wspomniane wiersze Szymborskiej, Herberta i Kozioł w zasadzie nie proponują osądu samobójstwa, ale też nie zawierają przeświadczenia o tym, że śmierć samobójcza była nieunikniona.

W wierszu Pokój samobójcy Herberta postać samobójcy jest pochodną przedstawienia samobójstwa jako desperackiego kroku. Herbert poprzez ironiczno-opisowy rejestr sugeruje dystans wobec samobójcy, będący raczej niemożliwością zrozumienia, aniżeli niemożnością współodczuwania:

Był taki teatralny. Stanął przed lustrem w czarnym ubraniu z kwiatem w butonierce. Włożył do ust narzędzie, czekał, aż lufa ociepli się i uśmiechając się z roztargnieniem do swego odbicia — strzelił. Spadł jak płaszcz zrzucony z ramion, ale dusza stała jeszcze jakiś czas potrzasając głową coraz lżejszą, coraz lżejszą $[\ldots]^{10}$.

${ }^{10}$ Z. Herbert, Samobójca, [w:] tenże, Hermes pies i gwiazda, Wrocław 1997, s. 163. 
Ironia wydaje się być zbawiennym tropem, który pomaga pojąc to, czego nie sposób pojąć: śmierć. Ironię odnajdujemy także w wierszu Pan Cogito o postawie wyprostowanej, oto fragment:

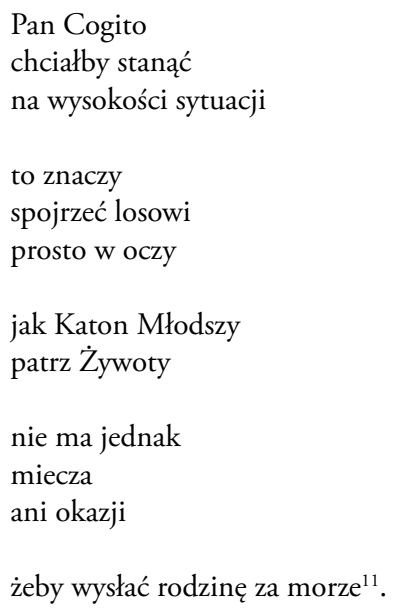

Jak zauważa Stefan Chwin, odwołanie do Katona, którego samobójcza śmierć jest tylko jednym z licznych czynów suicydalnych, w jakie obfituje ikonografia europejska, przedstawia strategię nadwartościowania śmierci ${ }^{12}$. Herbert sięga po nią, by zironizować heroiczną gotowość na altruistyczną śmierć samobójczą. Z tą różnicą, że w wierszu Herberta mowa o dokonanym już akcie:

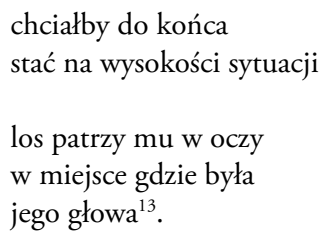

W swoim drugim, zdecydowanie bardziej znanym, wierszu Potęga smaku, Herbert także pośrednio porusza temat zabójstwa samego siebie, jednak tym razem chodzi o śmierć wolną (typ samobójstwa, które w języku niemieckim opisywane jest przy pomocy słowa Freitod):

[...] mieliśmy odrobinę niezbędnej odwagi lecz w gruncie rzeczy była to sprawa smaku Tak smaku

który każe wyjść skrzywić się wycedzić szyderstwo

${ }^{11}$ Z. Herbert, Pan Cogito o postawie wyprostowanej, [w:] tenże, Poezje wybrane, Kraków 2007, s. 88.

${ }^{12}$ S. Chwin, Samobójstwo jako doświadczenie wyobraźni, Gdańsk 2010, s. 404.

${ }^{13}$ Z. Herbert, Pan Cogito o postawie wyprostowanej, s. 88. 
choćby za to miał spaść bezcenny kapitel ciała glowa ${ }^{14}$.

Wyrażając postawę sprzeciwu wobec przemocy, Herbert mówi o możliwości dokonania właściwego wyboru, jednak z wyborem tym związane jest ryzyko: śmierć. Pośrednio jest to również sugestia tego, co moglibyśmy opisać jako dobrowolna, świadomie wybrana, śmierć.

Przedstawiona w wierszu Szymborskiej wizja samobójstwa pełna jest niuansów. Poetka nie wypowiada się ani na temat osoby, ani na temat czynu, mówi natomiast o miejscu, które zmarły zamieszkiwał. Pusty pokój pozwala jej na artylukację poczucia winy towarzyszącego osobom, które przybyły (niestety zbyt późno) z pomocą:

Myślicie pewnie, że pokój był pusty.

A tam trzy krzesła z mocnym oparciem.

Tam lampa dobra przeciw ciemności.

Biurko, na biurku portfel, gazety.

Budda niefrasobliwy, Jezus frasobliwy.

Siedem słoni na szczęście, a w szufladzie notes.

Myślicie, że tam naszych adresów nie było?

Myślicie, że przynajmniej list wyjaśniał coś.

A jeżeli wam powiem, że listu nie było -

i tylu nas — przyjaciół, a wszyscy się pomieścili

W pustej kopercie opartej o szklankę $e^{15}$.

Z kolei Urszula Kozioł buduje atmosferę, a tym samym i przesłanie wiersza, na głębokim poczuciu winy i empatii:

i wpakował w usta tę lodowatą

tę obcą jakimkolwiek dalszym ciągom

lufę

aż na moment

i mnie zastygła w żyłach

nasza krew

(a przecież mogłam w strasznej chwili

przynajmniej trzymać go za rękę) ${ }^{16}$.

Oprócz wiersza Potęga smaku Herberta, wszystkie spośrod zacytowanych dotąd wierszy samobójstwo traktują jako porażkę, kapitulację — poddanie się, dla którego być może istniała alternatywa, ale nie dostała swojej szansy — nie wskazują jednak winnego, choć można przypuszczać, że część odpowiedzialności ponoszą żyjący. Pomijając relację pomiędzy autorskim ja i samym aktem lub osobą samobójcy, w samo-

${ }^{14}$ Tenże, Potęga smaku, [w:] tenże, Poezje wybrane, s. 144.

${ }^{15}$ W. Szymborska, Pokój samobójcy, [w:] taż, Wiersze zebrane, Kraków 2004, s. 227.

${ }^{16}$ U. Kozioł, Temu kto postanowit odejść sam, [w:] taż, Przelotem, Kraków 2007, s. 65. 
bójstwie jako temacie poetyckim możemy dostrzec swoistą praktykę artystyczną, która swoim kreatywnym działaniem eliminuje traumatyczne elementy śmierci. Czy jednak sprawdza się to także w przypadku pisarzy, którzy uczynili z samobójstwa temat swojej poezji, a następnie wprowadzili swoje słowo w czyn? Czy w tym przypadku mamy do czynienia z fiaskiem takiej strategii czy też, wręcz przeciwnie, chodzi raczej o radykalny gest unicestwienia, pokonanie śmierci poprzez podjęcie decyzji o tym, kiedy nastąpi? Za ilustrację tej kwestii może posłużyć casus Wojaczka, który w wierszu Koniec świata zdaje się parafrazować znany dylemat Camusa: „Mam się zabić, czy pójść na kawę?” Więc można się zabić bez spektaklu, bez szeregu obrazów wirujących przed oczyma i sumujących całe dotychczasowe życie, bez efektownej, a zarezem wstrząsającej scenografii i burzy w ludzkim wnętrzu. Samobójstwo w tym tekście pokazane jest jako coś nieuniknionego, co na pewno nastąpi, przy czym w gestii jednostki, jako wyraz jej wolnej woli, leży podjęcie decyzji o tym, kiedy ono nastąpi:

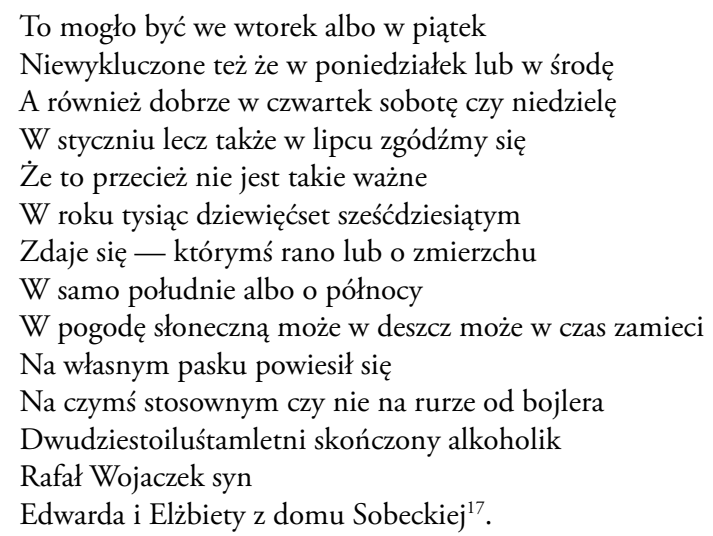

Wojaczek bardzo często poruszał temat samobójstwa, zapowiadając go w swoich wierszach. $Z$ drugiej strony, poprzez związaną z tym ekspresję, w pewnym sensie sam kreował kształt zarówno własnego życia, jak i własnej śmierci. W przypadku Wojacz$\mathrm{ka}$,„sam akt pisania o samobójstwie (czy pisania samobójstwa) był już imaginacyjną próbą tego, co ma być zrobione"18.

Z kolei Stachura w swojej poezji przesyconej kwestiami egzystencjalnymi, wolnością, cierpieniem i śmiercią zdaje się tworzyć poetycką wizję samobójstwa według Sartre’a. To właśnie dla francuskiego filozofa śmierć jest przede wszystkim fenomenem humanistycznym, a nie miejscem spotkania z czymś pozbawionym humanizmu. Śmierć jest ostatnią instancją życia, śmierć nadal jest życiem, jest uwewnętrzniona i jako taka zawsze zindywidualizowana. Sartre opisuje ją jako fenomen „mojego”, własnego życia, jako coś, co czyni go wyjątkowym. Również stosunek wobec zmarłych uważa się za

\footnotetext{
${ }_{17}$ R. Wojaczek, Koniec świata, [w:] tenże, Wiersze zebrane (1964-1971), wyd. 5 popr., Wrocław 2011. s. 193.

${ }^{18}$ S. Chwin, dz. cyt., s. 345.
} 
składową „bycia dla drugiego” (ętre pour autrui). Wiersz-testament Edwarda Stachury List do pozostalych to potwierdza:

bo chciałem zbawić od wszelkiego złego ludzi wszystkich i świat cały i jeżeli tak się nie stało, to winy mojej w tym nie umiem znaleźć / bo wygląda, że już nic tu po mnie / [...] bo duszę się w tej klatce / bo samotna jest dusza moja aż do śmierci / bo kończy się w porę ostatni papier i już tylko krok i niech Żyje Życie / bo stanąłem na początku, bo pociągnął mnie Ojciec i stanę na końcu i nie skosztuję śmierci ${ }^{19}$.

Według Chwina, teksty literackie Stachury stanowią przykład jednej ze strategii odwartościowania śmierci w formie przedsamobójczej gry ze śmiercią właśnie. Stachura starał się udowodnić sobie samemu, że nie włada nim biologiczny strach, który „żelaznym uściskiem trzyma nas przy życiu” ${ }^{20}$.

Ani u pisarzy, którzy mówią o cudzym samobójstwie, ani u tych, którzy piszą o własnym, nie znajdujemy lirycznego uszlachetniania samobójczych skłonności czy zamiarów, nie w sensie ich gloryfikacji czy usprawiedliwiania. Czy chodzi zatem o opiewanie samobójstwa (a więc śmierci), próbę jej pokonania jak w wierszu Szymborskiej („Radość pisania. / Możność utrwalania. / Zemsta ręki śmiertelnej”) czy też o akceptację śmierci poprzez spokojne poddanie się jej władzy? A może jednak mamy do czynienia z czymś innym? Tak czy inaczej, właśnie takie przykłady literackie skłaniają do ponownego przeanalizowania zaproponowanego przez Jeana Baechlera zindywidualizowango podejścia do samobójstwa. Autor książki Samobójstwo stwierdza, iż dobrowolną śmierć należy rozpatrywać na przykładzie konkretnych przypadków, gdyż odebranie sobie życia zawsze jest działaniem indywidualnym.

Kwestię relacji pomiędzy literaturą a śmiercią w subtelny sposób poruszał również eseista, pisarz i filozof Maurise Blanchot, który wciąż od nowa zadawał w swoich tekstach pytanie: „Czym jest literatura?”, łącząc je z problemem śmierci. Blanchot rozmyślał nad doświadczeniem śmierci, uznając jednocześnie, że rozważania takie możliwe są jedynie w dziedzinie literatury. Przy czym nie chodzi wcale o prawdziwą śmierć, ale o to, by w śmierci, czy dokładniej w znikaniu podmiotu, odkryć warunek istnienia literatury. Według niego, pojęcie śmierci rodzącej doświadczenie literatury przeciwstawia się filozoficznym konceptom. Literatura zatem rozpoczyna się od pytania, czy też staje się pytaniem. Zaczyna się od pytania o własne możliwości, a jej istnienie jest powtarzaniem początku, początku, który nie zawiera w sobie żadnej treści. Literatura więc nie ma żadnej wcześniejszej istoty i od początku istnieje jako własne zaprzeczenie, istnieje jako (własna) nieobecność. Refleksje Blanchot na temat literatury nie są jedynie czczym wymysłem, ale zasadzają się na analogii z rewolucją: od niczego ku wszystkiemu. Działalność rewolucyjna generowana jest z taką samą siłą i łatwością, jak twórcze działanie pisarza. Rewolucja, tak samo jak literatura, zamienia się w uniwersalną wolność, a w takiej sytuacji każdy ma prawo do swojej śmierci. Śmierć jest

${ }^{19}$ E. Stachura: List do pozostatych [online], dostęp 1 maja 2014, dostępny: <http://stachuriada.pl/stachura/twory/list.html>.

${ }^{20}$ S. Chwin, dz. cyt., s. 407. 
urzeczywistnieniem wolności, ale co ważne, ona też potwierdza fakt, że literatura jest abstrakcyjna, idealna (literacka). Literatura więc, jako ideał, przejmuje ten moment dziejowy, w którym życie z zalążkiem śmierci i w samej śmierci trwa ${ }^{21}$.

Istnieje nikła szansa, że samobójcy wspomniani na poczatku tekstu staną się literacką inspiracją. Są jednak wyraźnym sygnałem narastającego problemu: główną przyczyną odebrania sobie życia była bowiem sytuacja społeczno-ekonomiczna, a nie genetyczne obciążenie, czy jednostkowa patologia. Z kolei samobójstwom, które poprzez estetyczną obróbkę wchodzą do literatury współczesnej, przypisywane są pośrednio lub bezpośrednio szlachetne pobudki, a w tle pobrzmiewa zdanie francuskiego prozaika Henry’a De Montherlanta z Trzynastego Cesarza: „Nie ma nic bardziej tajemniczego od samobójstwa”22.

Đurđica Čilić Škeljo

\section{Suicide Motif in Contemporary Polish Poetry}

\section{Summary}

Distinctive and striking motif of suicide is present in contemporary Polish poetry in two ways, either as a discussion of or an announcement of one's own suicide, or as a reflexion, that is, lyrical interpretation of the suicide of others. On the basis of the existentialist treatment of suicide as an authentic act, the article aims to analyse similarities and differences of poetic presentation of the aforementioned types of suicide - one's own suicide, which always remains just an idea or a possibility, and other people's suicide, which becomes an object of post festum lyrical interpretation.

${ }^{21}$ Zob. M. Blanchot, Literature and the Right to Death [online], dostęp 10 maja 2014, dostępny: <http:// it.scribd.com/doc/20794063/Literature-and-the-Right-to-Death-by-Maurice-Blanchot>.

${ }^{22}$ H. de Montherlant: The Thirteenth Caesar, Death [online], dostęp 11 maja 2014, dostępny: <http://colleged.info/find-henry-de-montherlant>. 